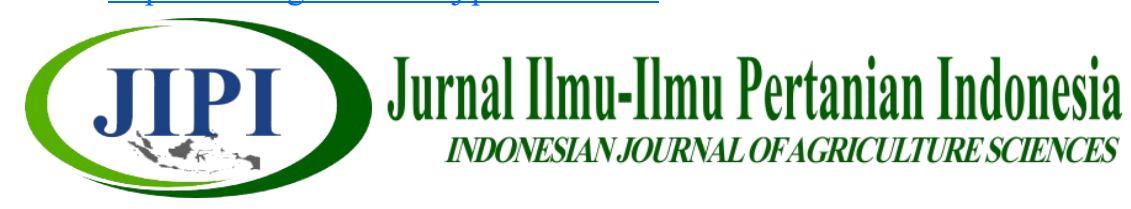

\title{
SERANGAN HAMA PENGGEREK POLONG PADA ENAM VARIETAS KEDELAI DAN PENGARUHNYA TERHADAP HASIL
}

\author{
Christiawan Poniman ${ }^{1}$, Tri Sunardi ${ }^{2 *}$, Hesti Pujiwati ${ }^{1}$ \\ ${ }^{1}$ Program Studi Agroekoteknologi, Fakultas Pertanian Universitas Bengkulu \\ ${ }^{2}$ Program Studi Proteksi Tanaman, Fakultas Pertanian Universitas Bengkulu \\ * Corresponding Author: trisunardi@unib.ac.id
}

\begin{abstract}
[THE ATTACK OF POD BORER AFFECTS THE YIELD OF SIX SOYBEAN VARIETIES]. This study was aimed to determine the level of pod borer attacks on six soybean varieties and the effects on yields. The field experiment was conducted in the Agricultural Experimental Center, the University of Bengkulu from December 2017 to March 2018. The experiment was to evaluate the responses of six soybean varieties, including var. Demas, Argomulyo, Dega, Ringing, Echo, and Dena-I, to pod borer attacks. Planting of six soybean varieties was organized in a completely randomized block design (CRBD) which was repeated 4 times as blocks. The results showed that the percentage of pod attack on var. Demas, Argomulyo, Ringing, Gema, and Dena-I were classified resistant, while var. Dega was relatively resistant. The percentage of attacked seedlings of soybean varieties were classified as resistant. Var. Argomulyo showed a higher resistance compared to other varieties because it produced the highest number of trichomes and the lowest number of larvae. Var. Argomulyo produced the heaviest of seed weight per plant and the seed weight per plot. Var. Echo produced the highest number of pods, while var. Dega produced the heaviest weight of 100 seeds.
\end{abstract}

Keyword: attack, pod borer, soybean variety, insect resistance

\begin{abstract}
ABSTRAK
Penelitian ini bertujuan untuk menentukan tingkat serangan hama penggerek polong pada enam varietas kedelai dan pengaruhnya terhadap hasil. Penelitian ini dilaksanakan pada bulan Desember 2017 sampai Maret 2018 di Lahan Percobaan Fakultas Pertanian Universitas Bengkulu Kelurahan Kandang Limun Kecamatan Muara Bangkahulu, Kota Bengkulu. Rancangan percobaan yang digunakan yaitu Rancangan Acak Kelompok Lengkap (RAKL) dengan perlakuan enam varietas kedelai (Demas, Argomulyo, Dega, Dering, Gema, dan Dena I) dan diulang 4 kali sehingga terdapat 24 satuan percobaan. Hasil penelitian menunjukkan bahwa persentase serangan polong pada varietas Demas, Argomulyo, Dering, Gema, dan Dena I tergolong tahan, sedangkan varietas Dega tergolong agak tahan. Sedangkan persentase serangan biji pada semua varietas kedelai yang diuji tergolong tahan. Varietas Argomulyo memiliki ketahanan terhadap serangan hama penggerek polong lebih tinggi dari varietas lainnya karena menghasilkan jumlah trikoma tertinggi, dan jumlah larva/ tanaman terendah. Varietas Argomulyo menghasilkan bobot biji/tanaman tertinggi, serta bobot biji/petak terberat. Varietas Gema menghasilkan jumlah polong total terbanyak, sedangkan varietas Dega menghasilkan bobot 100 biji terberat.
\end{abstract}

Kata kunci: $\quad$ hama penggerek polong, varietas kedelai, persentase serangan 


\section{PENDAHULUAN}

Kedelai (Glycine max L. Merrill) merupakan salah satu bahan pangan penting sebagai sumber protein nabati yang tinggi dan dikonsumsi setiap hari oleh masyarakat Indonesia. Kebutuhan kedelai di Indonesia mencapai $\pm 2,2$ juta ton per tahun sedangkan produksi dalam negeri hanya mampu memenuhi 35 - 40\% dari kebutuhan kedelai di Indonesia (Marwoto \& Suharsono, 2010). Berdasarkan data Kementerian Pertanian Republik Indonesia (2018) produksi kedelai tahun 2014 sampai dengan tahun 2017 mengalami fluktusi. Pada 2014 produksi kedelai sebesar 954.997 ton, meningkat menjadi 963.183 ton pada 2015. Produksi kedelai mengalami penurunan pada tahun 2016 dan 2017 secara berturutturut menjadi 859.653 ton dan 538.728 ton.

Beberapa kendala yang menghambat peningkatan produksi dalam negeri di antaranya, minat petani dalam bertanam kedelai rendah, produktifitas kedelai rendah, inovasi yang lamban, kemitraan yang belum berkembang serta serangan hama dan penyakit (Ridhayat, 2012). Salah satu hama utama pada pertanaman kedelai di Indonesia adalah penggerek polong (Etilla zinckenella). Spesies penggerek polong lainnya di Indonesia $E$. hubsoni Butler, E. chrysoporella Meyrick, E. griseadrososcia Meyrick Stat.n., dan E. behrii Zeller (Tengkano et al., 2007). Spesies yang dominan dan memiliki daerah penyebaran yang luas adalah $E$. zinckenella. Informasi mengenai bioekologi dan daerah penyebaran empat spesies penggerek polong lainnya masih terbatas.

Stadia penggerek polong yang merusak kedelai adalah larva. Larva penggerek polong menyerang dengan cara membuat lubang gerekan pada polong lalu merusak biji dengan meninggalkan kotoran hasil gerekan (Tohamy \& El-Hafez, 2005). Kehilangan hasil akibat serangan penggerek polong dapat mencapai $80 \%$, bahkan puso apabila tidak ada tindakan pengendalian (Djuwarso et al., 1990).

Penggunaan varietas tahan hama merupakan salah satu bagian dalam program pemuliaan yang masih terus dikembangkan. Hal ini dilakukan agar program pemuliaan dilakukan lebih terarah, efektif dan efisien (Andayanie et al., 2011) serta penggunaan varietas tahan merupakan cara yang aman bagi lingkungan dan lebih ekonomis (Baliadi et al., 2008). Sifat ketahanan terhadap serangga dapat dilacak melalui seleksi karakteristik morfologi dan anatomi daun. Morfologi tanaman (batang, daun dan polong) antara lain memiliki struktur bulu yang sangat beragam hal tersebut diduga dapat mempengaruhi tingkat ketahanan kedelai terhadap serangga hama. Struktur bulu (trikoma), ukuran panjang, dan kerapatan trikoma sangat berpengaruh terhadap ketahanan tanaman kedelai, yang berarti semakin tinggi kerapatan trikoma daun maka semakin rendah intensitas serangan, begitu juga sebaliknya (Minarno \& Khoiriyah, 2011).

Trikoma merupakan organ tanaman yang berhubungan langsung pada tahap awal penerimaan inang (host acceptance) (Suharsono \& Suntono, 2004). Fakta menunjukkan bahwa kerusakan tanaman oleh serangga lebih rendah dengan meningkatnya kerapatan trikoma artinya berkorelasi negatif dengan kerapatan trikoma (Suharsono \& Suntono 2004). Karakteristik polong kedelai pada galur IAC-100 dan IAC-80-596-2 dengan trikoma yang panjang dan rapat merupakan faktor ketahanan galur tersebut terhadap hama pengisap polong Riptortus linearis (Suharsono, 2001).

Penelitian mengenai ketahanan varietas tanaman terhadap serangan hama penggerek polong sampai saat ini masih jarang dilakukan. Di sisi lain ketahanan varietas kedelai terhadap serangan merupakan salah satu kunci dalam keberhasilan budidaya kedelai. Sehubungan dengan pengembangan kedelai di Bengkulu, diperlukan varietas yang tahan terhadap serangan hama penggerek pohon. Beberapa varietas kedelai dipilih untuk pengembangan baru diketahui produktifitasnya yang baik, namun belum diketahui ketahanannya terhadap serangan hama penggerek polong di Bengkulu. Oleh karena itu perlu dilakukan penelitian untuk mendapatkan varietas kedelai yang toleran terhadap serangan hama penggerek polong.

Penenelitian ini menggunakan 6 varietas kedelai untuk diuji ketahanannya terhadap hama penggerek polong yaitu Demas, Argomulyo, Dega, Dering, Gema, dan Dena I. Kedelai varietas Demas dilepas pada 12 November 2014 memiliki umur masak \pm 84 hst, berbiji sedang (13 g/100 biji) dengan potensi hasil 2,5 ton/ha dan rata-rata hasil $\pm 1,7$ ton/ha, umur berbunga \pm 37 hari, memiliki tipe tumbuh determinate, jumlah polong \pm 64 per tanaman, tinggi tanaman $\pm 66,3 \mathrm{~cm}$, tahan rebah, serta tahan terhadap penyakit karat daun (Phakopsora pachirhyzi Syd), penggerek polong (Etiella zinckenella), agak rentan hama pengisap polong (Riptortus linearis), dan rentan hama ulat grayak (Spodoptera litura F.) (Balitkabi, 2016).

Kedelai varietas Argomulyo dilepas pada 1998 memiliki umur masak 80-82 hst, berbiji besar (16 g/100 biji) dengan potensi hasil 1,5-2,0 ton/ha, umur berbunga \pm 35 hari, memiliki tipe tumbuh determinate, tinggi tanaman $\pm 40 \mathrm{~cm}$, tahan rebah, serta toleran karat daun (Balitkabi, 2016). Kedelai varietas Dega dilepas pada 5 September 2016 memiliki umur masak 69-73 hst, berbiji besar ( $22,98 \mathrm{~g} / 100 \mathrm{biji})$ dengan potensi hasil 3,82 ton/ha, umur berbunga \pm 29 hari, memiliki tipe tumbuh determinate, tinggi tanaman \pm $53 \mathrm{~cm}$, agak tahan terhadap penyakit karat daun (Phakopsora pachirhyzi Syd), dan rentan terhadap hama ulat grayak (Spodoptera litura F.) (Balitkabi, 2016).Kedelai varietas Dering dilepas pada 25 September 2012 memiliki umur masak \pm 81 hst, berbiji kecil (10,7 g/100 biji) dengan potensi hasil 2,8 ton/ha, umur berbunga \pm 35 hari, memiliki tipe tumbuh determinate, tinggi tanaman $\pm 57 \mathrm{~cm}$, tahan 
hama penggerek polong (Etiella zinckenella), rentan ulat grayak (Spodoptera litura), dan tahan penyakit karat daun (Phakopsora pachyrhizi) (Balitkabi, 2016). Kedelai varietas Gema dilepas pada 9 Desember 2011 memiliki umur masak \pm 73 hst, berbiji sedang $(11,90 \mathrm{~g} / 100 \mathrm{biji})$ dengan potensi hasil 3,06 ton/ha, umur berbunga \pm 36 hari, memiliki tipe tumbuh determinate, tinggi tanaman $\pm 55 \mathrm{~cm}$, peka terhadap virus daun CMMV, moderat penyakit kara, peka terhadap hama pengisap polong, agak tahan hama penggerek polong, dan moderat terhadap hama ulat grayak (Balitkabi, 2016). Kedelai varietas Dena I dilepas pada 5 Desember 2014 memiliki umur masak \pm 78 hst, berbiji besar (14,3 g/100 biji) dengan potensi hasil 2,9 ton/ha, umur berbunga \pm 33 hari, memiliki tipe tumbuh determinate, tinggi tanaman $\pm 59 \mathrm{~cm}$, tahan terhadap penyakit karat daun (Phakopsora pachirhyzi Syd.), rentan hama pengisap polong (Riptortus linearis) dan hama ulat grayak (Spodoptera litura F.) (Balitkabi, 2016)

Penelitian ini bertujuan untuk menentukan tingkat serangan hama penggerek polong pada enam varietas kedelai dan pengaruhnya terhadap hasil.

\section{METODE PENELITIAN}

Penelitian ini dilaksanakan pada bulan Desember 2017 sampai Maret 2018 di Lahan Percobaan Fakultas Pertanian Universitas Bengkulu Kelurahan Kandang Limun Kecamatan Muara Bangkahulu, Kota Bengkulu.

Rancangan percobaan yang digunakan yaitu Rancangan Acak Kelompok Lengkap (RAKL) dengan perlakuan enam varietas varietas kedelai $\left(\mathrm{V}_{1}=\right.$ Demas, $\mathrm{V}_{2}$ $=$ Argomulyo, $\mathrm{V}_{3}=$ Dega, $\mathrm{V}_{4}=$ Dering, $\mathrm{V}_{5}=$ Gema, dan $\mathrm{V}_{6}=$ Dena I) dan diulang 4 kali sehingga terdapat 24 satuan percobaan.

Persiapan lahan dimulai dengan pembebasan gulma dan pengolahan tanah menggunakan cangkul kemudian dibuat petakan dengan ukuran $2 \mathrm{~m} \times 2 \mathrm{~m}$. Pengolahan tanah dilakukan sekaligus dengan penambahan 10 ton/ha pupuk kandang sapi, $50 \mathrm{~kg} / \mathrm{ha}$ urea, $75 \mathrm{~kg} /$ ha TSP, dan $50 \mathrm{~kg} \mathrm{KCl}$. Jarak antar petak $50 \mathrm{~cm}$. Aplikasi pupuk TSP, dan $\mathrm{KCl}$ dilakukan pada saat tanam. Sedangkan pupuk urea diberikan 2 kali yaitu saat tanam sebanyak $25 \mathrm{~kg} / \mathrm{ha}$ dan pada saat tanaman telah berbunga yaitu sebanyak $25 \mathrm{~kg} / \mathrm{ha}$.

Lahan yang telah diolah kemudian dibuat lubang tanam menggunakan penugal yang terbuat dari kayu dengan kedalaman $\pm 5 \mathrm{~cm}$. Jarak tanam yang dipakai adalah $20 \mathrm{~cm} \times 40 \mathrm{~cm}$ sehingga dalam satu satuan percobaan terdapat 50 tanaman. Jumlah benih per lubang yang ditanam yaitu dua benih kedelai. Jarak antar ulangan adalah $100 \mathrm{~cm}$, sedangkan jarak antar petak dalam ulangan adalah $50 \mathrm{~cm}$.

Pemeliharaan yang dilakukan meliputi penyiraman tanaman, penyulaman, penjarangan, dan penyiangan. Penyiraman dilakukan setiap hari pada sore hari yaitu sekitar pukul 4 atau 5 sore jika tidak turun hujan. Penyulaman dilakukan jika ada benih yang tidak tumbuh. Penjarangan dilakukan dengan cara memotong menggunakan gunting pada salah satu tanaman di lubang tanam yang tumbuh 2 tanaman. Penyiangan dilakukan secara mekanik.

Panen kacang kedelai dilakukan pada saat tanaman berumur kurang lebih 85 hari setelah tanam atau ketika daun dan polong tanaman telah berwarna kecoklatan dan mengering. Peubah yang diamati meliputi tinggi tanaman, diameter batang, jumlah trikoma polong, jumlah polong terserang/tanaman, jumlah polong total/tanaman, persentase kerusakan polong, persentase kerusakan biji, jumlah larva penggerek polong, bobot biji/tanaman, bobot 100 biji, dan bobot biji/ petak.

Persentase kerusakan polong (\%) ditentukan atas dasar persamaan (Bayu et al., 2017) :

$$
\mathrm{I}=\frac{a}{a+b} \times 100 \%
$$

Keterangan : $\mathrm{I}=$ persentase kerusakan polong $(\%) ; \mathrm{a}=$ jumlah polong yang terserang; $b=$ jumlah polong yang tidak terserang

Untuk menentukan tingkat ketahanan tanaman menggunakan metode seperti yang dilakukan oleh Asadi (2009) sebagai berikut:

Skor 1 , serangan $0-20 \%=$ tahan

Skor 2, serangan $21-40 \%=$ agak tahan

Skor 3, serangan $41-60 \%=$ agak rentan

Skor 4 , serangan $61-80 \%=$ rentan

Skor 5 , serangan $>80 \%=$ sangat rentan

Ciri-ciri polong kedelai terserang hama penggerek polong adalah terdapat lubang gerek berbentuk bundar pada kulit polong. Apabila terdapat dua lubang gerek pada polong berarti ulat sudah meninggalkan polong (Marwoto et al., 2017). Persentase kerusakan biji dihitung dengan persamaan Bayu et al. (2017) .

Data yang diperoleh dianalisis menggunakan analisis varian (ANAVA). Jika terdapat pengaruh nyata atau sangat nyata dilakukan DMRT taraf 5\%.

\section{HASIL DAN PEMBAHASAN}

Hasil analisis data menunjukkan bahwa varietas kedelai berpengaruh sangat nyata $(P \leq 0,01)$ terhadap jumlah trikoma, jumlah polong total/tanaman, jumlah larva/tanaman, bobot biji/ tanaman, bobot 100 biji, dan bobot biji/petak, namun berpengaruh tidak nyata $(\mathrm{P}>0,05)$ terhadap tinggi tanaman, diameter batang, jumlah polong terserang/tanaman, persentase kerusakan polong/tanaman, dan persentase kerusakan biji/tanaman.

Varietas Dering menghasilkan jumlah polong terserang yang cenderung lebih rendah yaitu 5,25 polong, akan tetapi varietas Argomulyo memiliki persentase 
kerusakan polong/ tanaman dan persentase kerusakan biji/tanaman cenderung lebih rendah yaitu secara berturut-turut sebesar $13,11 \%$, dan $8,52 \%$. Persentase serangan polong pada varietas Demas, Argomulyo, Dering, Gema, dan Dena I tergolong tahan, sedangkan varietas Dega tergolong agak tahan. Sedangkan persentase serangan biji pada semua varietas kedelai yang diuji tergolong tahan (Tabel 1).

Serangan hama penggerek polong berhubungan erat dengan trikoma polong. Secara umum hasil penelitian menunjukkan bahwa peningkatan jumlah trikoma cenderung diikuti dengan menurunnya serangan hama penggerek polong. Menurut Susanto \& Adie (2008) salah satu faktor penghambat mekanis bagi penggerek polong saat menyerang polong adalah adanya trikoma dengan karakteristik yang rapat dan panjang. Hasil penelitian Tamang et al. (2017) menunjukkan bahwa tingkat serangan hama dipengaruhi oleh kepadatan trikoma pada permukaan tanaman. Kepadatan trikoma polong menjadi salah satu faktor ketahanan terhadap penggerek polong baik imago maupun larva pada tanaman kedelai (Bayu et al., 2015).

Varietas Argomulyo menghasilkan jumlah trikoma terbanyak, yang berbeda tidak nyata dengan varietas Gema, namun berbeda nyata dengan varietas Demas, Dega, Dering, dan Dena I. Varietas Demas menghasilkan jumlah trikoma terendah yang berbeda nyata dengan varietas lainnya. Jumlah trikoma pada varietas Argomulyo adalah 24,75, sedangkan jumlah trikoma pada varietas Demas adalah 8,00 (Tabel 2). Perbedaan jumlah trikoma pada masing-masing varietas diduga karena pengaruh genetika masing-masing varietas tersebut. Setiap varietas atau galur mempunyai ragam kerapatan trikoma yang berbeda tergantung oleh varietas atau jenis kedelai (Sari \& Suharsono, 2010). Kerapatan trikoma pada kedelai dikendalikan oleh gen tunggal dan bersifat resesif (Adie et al., 2000).

Jumlah larva/tanaman terendah dihasilkan oleh varietas Argomulyo yang berbeda tidak nyata $(\mathrm{P}>$ $0,05)$ dengan varietas Demas, dan Dega, namun berbeda nyata $(\mathrm{P} \leq 0,05)$ dengan varietas Dering, Gema, dan Dena I. Sedangkan varietas Gema menghasilkan jumlah larva/tanaman terbanyak yang berbeda tidak nyata dengan varietas Dena I, namun berbeda nyata dengan varietas Demas, Argomulyo, Dega, dan Dering. Jumlah larva per tanaman pada varietas Argomulyo adalah 8 ekor, sedangkan jumlah larva/tanaman pada varietas Gema adalah 23,25 ekor (Tabel 2).

Trikoma pada permukaan tanaman adalah organ tanaman yang berhubungan langsung pada tahap awal penerimaan inang (host acceptance). Fakta menunjukkan bahwa kerusakan tanaman oleh serangga lebih rendah dengan meningkatnya kerapatan trikoma artinya berkorelasi negatif dengan kerapatan trikoma (Suharsono \& Suntono, 2004). Trikoma mempersulit peneluran imago penggerek polong pada kulit polong. Semakin sedikit jumlah trikoma semakin tinggi jumlah telur. Salah satu faktor penghambat mekanis bagi penggerek polong saat menyerang polong adalah adanya trikoma dengan karakteristik yang rapat dan panjang. Trikoma dapat menjadi tempat ideal pada sebagian hama untuk menempatkan telur supaya tidak rusak karena gangguan lingkungan (Susanto \& Adie, 2008). Trikoma pada kulit polong kedelai merupakan karakter fisik potensial penentu ketahanan terhadap hama pengisap polong (Suharsono, 1997). Semakin banyak jumlah telur, semakin banyak populasi larva maka intensitas serangan semakin tinggi. Telur banyak ditemukan di daun,bunga dan polong tetapi larva hanya terdapat di polong (Baliadi et al. 2008

Tabel 1. Rata-rata jumlah polong terserang/tanaman, persentase kerusakan polong/tanaman, dan persentase kerusakan biji/tanaman

\begin{tabular}{lccccc}
\hline Varietas & $\begin{array}{c}\text { Jumlah } \\
\text { polong } \\
\text { terserang/ } \\
\text { tanaman }\end{array}$ & $\begin{array}{c}\text { Persentase } \\
\text { kerusakan } \\
\text { polong/ } \\
\text { tanaman (\%) }\end{array}$ & $\begin{array}{c}\text { Tingkat } \\
\text { ketahanan }\end{array}$ & $\begin{array}{c}\text { Persentase } \\
\text { kerusakan biji/ } \\
\text { tanaman (\%) }\end{array}$ & $\begin{array}{c}\text { Tingkat } \\
\text { ketahanan }\end{array}$ \\
\hline Demas & 10,00 & 19,08 & Tahan & 13,56 & Tahan \\
Argomulyo & 10,00 & 13,11 & Tahan & 8,52 & Tahan \\
Dega & 6,00 & 21,37 & Agak tahan & 14,45 & Tahan \\
Dering & 5,25 & 15,01 & Tahan & 11,07 & Tahan \\
Gema & 12,50 & 14,98 & Tahan & 9,98 & Tahan \\
Dena I & 6,75 & 15,03 & Tahan & 10,34 & Tahan \\
\hline
\end{tabular}


Tabel 2. Rata-rata jumlah trikoma dan jumlah larva/ tanaman akibat serangan hama penggerek pada enam varietas kedelai

\begin{tabular}{l|c|c}
\hline \multicolumn{1}{c}{ Varietas } & Jumlah trikoma & Jumlah larva/tanaman \\
\hline Demas & $8,00 \mathrm{~d}$ & $12,50 \mathrm{bc}$ \\
\hline Argomulyo & $24,75 \mathrm{a}$ & $8,00 \mathrm{c}$ \\
\hline Dega & $15,50 \mathrm{c}$ & $10,00 \mathrm{c}$ \\
\hline Dering & $16,00 \mathrm{bc}$ & $15,50 \mathrm{~b}$ \\
\hline Gema & $21,50 \mathrm{ab}$ & $23,25 \mathrm{a}$ \\
\hline Dena I & $15,00 \mathrm{c}$ & $21,25 \mathrm{a}$ \\
\hline
\end{tabular}

Keterangan : angka-angka yang diikuti oleh huruf yang sama pada

kolom yang sama berbeda tidak nyata pada DMRT $5 \%$

Secara rata-rata terlihat bahwa jumlah polong total tertinggi dihasilkan oleh varietas Gema yang berbeda tidak nyata $(\mathrm{P}>0,05)$ dengan varietas Argomulyo, namun berbeda nyata dengan varietas Demas, Dega, Dering, dan Dena I. Sedangkan varietas Dega menghasilkan jumlah polong total terendah yang berbeda tidak nyata dengan varietas Dering, namun berbeda nyata dengan varietas Demas, Argomulyo, Dega, Gema dan Dena I. Jumlah polong total pada varietas Gema adalah 84 polong, sedangkan jumlah polong total pada varietas Dega I adalah 27,75 polong (Tabel 3). Hal ini diduga karena varietas Gema dan Argomulyo mampu beradaptasi dengan lingkungan lebih baik dibandingkan dengan varietas lainnya. Varietas Wilis memiliki daya adaptasi yang lebih baik dibandingkan varietas Anjasmoro (Kriswantoro et al., 2012). Interaksi antara genetik dan lingkungan yang mempengaruhi pertumbuhan tinggi tanaman kedelai. Bakhtiar \& Waluyo (2013) menambahkan bahwa semakin baik kemampuan tanaman beradaptasi dengan lingkungan, maka semakin baik pertumbuhannya. Penggunaan varietas yang berbeda akan menyebabkan pertumbuhan dan produksi yang berbeda (Efendi, 2010). Perbedaan yang nyata antara varietas tersebut disebabkan oleh interaksi faktor lingkungan tumbuh dengan faktor genetik.

Tabel 3. Rata-rata hasil enam varietas kedelai

\begin{tabular}{|l|l|c|c|c|}
\hline Varietas & $\begin{array}{c}\text { Jumlah polong } \\
\text { total tanaman }\end{array}$ & $\begin{array}{c}\text { Bobot biji } \\
\text { tanaman }(\mathrm{g})\end{array}$ & $\begin{array}{c}\text { Bobot } 100 \\
\text { biji }(\mathrm{g})\end{array}$ & $\begin{array}{c}\text { Bobot biji } \\
\text { petak }(\mathrm{g})\end{array}$ \\
\hline Demas & $51,00 \mathrm{~b}$ & $12,57 \mathrm{c}$ & $12,33 \mathrm{~d}$ & $629,77 \mathrm{c}$ \\
\hline Argomulyo & $79,00 \mathrm{a}$ & $24,11 \mathrm{a}$ & $15,38 \mathrm{~b}$ & $1008,07 \mathrm{a}$ \\
\hline Dega & $27,75 \mathrm{~d}$ & $10,88 \mathrm{c}$ & $21,38 \mathrm{a}$ & $543,93 \mathrm{~d}$ \\
\hline Dering & $35,00 \mathrm{~cd}$ & $7,13 \mathrm{~d}$ & $10,33 \mathrm{f}$ & $359,24 \mathrm{e}$ \\
\hline Gema & $84,00 \mathrm{a}$ & $19,02 \mathrm{~b}$ & $11,40 \mathrm{e}$ & $950,60 \mathrm{~b}$ \\
\hline Dena I & $44,25 \mathrm{bc}$ & $12,09 \mathrm{c}$ & $13,95 \mathrm{c}$ & $613,50 \mathrm{c}$ \\
\hline
\end{tabular}

Keterangan : angka-angka yang diikuti oleh huruf yang sama pada kolom yang sama berbeda tidak nyata pada DMRT $5 \%$

Varietas Argomulyo menghasilkan bobot biji/ tanaman tertinggi yang berbeda nyata dengan varietas lainnya. Sedangkan varietas Dering menghasilkan bobot biji/tanaman terendah yang berbeda nyata dengan varietas lainnya. Bobot biji/tanaman pada varietas Argomulyo adalah 24,11 g, sedangkan bobot biji/tanaman pada varietas Gema adalah 7,13 g (Tabel 3). Potensi daya hasil biji yang tinggi dari varietas unggul dapat tercapai jika lingkungan tumbuh tanaman dikelola dengan optimal (Adisarwanto, 2006). Tanaman yang toleran terhadap cekaman lingkungan mempunyai kemampuan untuk beradaptasi secara morfologi dan fisiologi (Utama, 2008)..

Bobot biji/tanaman berhubungan erat dengan jumlah polong total/tanaman. Tinggi bobot biji/tanaman pada varietas Argulmulyo dibandingkan dengan varietas lain karena memiliki jumlah polong total/tanaman lebih tinggi (Tabel 3). Jumlah biji/tanaman berkorelasi positif dengan jumlah polong/tanaman (Dwiputra et al., 2015). Hal ini berarti bahwa semakin banyak jumlah polong/tanaman maka semakin berat bobot biji/tanaman.

Varietas Dega menghasilkan bobot 100 biji terberat yang berbeda nyata dengan varietas lainnya. Sedangkan varietas Dering menghasilkan bobot 100 biji terendah yang berbeda nyata dengan varietas lainnya. Bobot 100 biji pada varietas Dega adalah 21,38 g, sedangkan bobot 100 pada varietas Dering adalah 10,33 g (Tabel 3). Menurut Fachruddin (2000) ukuran biji diklasifikasikan menjadi 3 kelas yaitu biji kecil (6-10 $\mathrm{g} / 100$ biji), biji sedang (11-12 g/100 biji), dan biji besar (13 g atau lebih/100 biji). Berdasarkan klasifikasi tersebut maka ukuran biji pada varietas Dering tergolong berukuran kecil, varietas Gema dan Demas tergolong berukuran sedang, serta varietas Argomulyo, Dega, dan Dena I tergolong berukuran besar.

Perbedaan bobot 100 biji diduga karena sifat genetik tanaman. Soegito \& Arifin (2004) menjelaskan bahwa varietas mempunyai keunggulan genetis yang berbeda-beda sehingga perbedaan pada varietas kedelai yang ditanam memiliki produksi yang berbeda pula, tergantung pada sifat varietas tanaman itu sendiri. Kenaikan bobot 100 biji disebabkan faktor genetik dari varietas kedelai. Semakin besar ukuran biji maka semakin besar bobot 100 biji serta kemampuan tanaman mengabsorbsi hara dari lingkungan. Hal ini sesuai dengan hasil penelitian Sumardi (2014) yang menunjukkan bahwa sifat genetik tanaman salah satunya ukuran biji dari masing-masing varietas kedelai mempengaruhi bobot 100 biji tanaman. Selain itu tinggi rendahnya hasil yang didapatkan juga ditentukan oleh ukuran biji.

Varietas Argomulyo menghasilkan bobot biji/petak terberat yang berbeda nyata dengan varietas lainnya. Sedangkan varietas Dering menghasilkan bobot biji/ petak terendah yang berbeda nyata dengan varietas lainnya. Bobot biji/petak pada varietas Argomulyo adalah 1008,07 g sedangkan bobot biji/petak pada varietas Dering adalah 359,24 g (Tabel 3). Hal ini diduga karena varietas Argomulyo memiliki ketahanan terhadap serangan penggerek polong lebih baik daripada varietas lainnya, yang terlihat dari jumlah trikomanya lebih banyak, serta jumlah larvanya lebih sedikit. 
Salah satu faktor penghambat mekanis bagi penggerek polong saat menyerang polong adalah adanya trikoma dengan karakteristik yang rapat dan panjang. Trikoma dapat menjadi tempat ideal pada sebagian hama untuk menempatkan telur supaya tidak rusak karena gangguan lingkungan (Susanto \& Adie, 2008). Trikoma pada kulit polong kedelai dilaporkan sebagai karakter fisik potensial penentu ketahanan terhadap hama pengisap polong (Suharsono, 1997).

\section{KESIMPULAN}

Persentase serangan polong pada varietas Demas, Argomulyo, Dering, Gema, dan Dena I tergolong tahan, sedangkan varietas Dega tergolong agak tahan. Persetase serangan biji pada semua varietas kedelai yang diuji tergolong tahan.

Varietas Argomulyo memiliki ketahanan terhadap serangan hama penggerek polong lebih tinggi dari varietas lainnya. Varietas Argomulyo menghasilkan jumlah bobot biji/ tanaman tertinggi, serta bobot biji/ petak tertinggi. Varietas Gema menghasilkan jumlah polong total tertinggi, sedangkan varietas Dega I menghasilkan bobot 100 biji tertinggi.

\section{DAFTAR PUSTAKA}

Adie, M.M., K., Tridjaka, I. \& Suharsono. (2000). Genetika ketahanan antibiosis kedelai terhadap ulat grayak. Prosiding Seminar Balitkabi. Pengelolaan Sumberdaya Lahan dan Hayati pada Tanaman Kacang-kacangan dan Umbi-umbian. Balitkabi. Pusat Penelitian dan Pengembangan Tanaman Pangan, Bogor.

Adisarwanto, T. 2006. Kedelai. Penebar Swadaya, Jakarta.

Andayanie, W.R, Sumardiyono, Y.B., Hartono, S. \& Yudono, P. (2011). Incidence of soybean mosaic disease in East Java Province. J Agrivita, 33(1), $15-22$.

Asadi. (2009). Identifikasi ketahanan sumber daya genetik kedelai terhadap hama pengisap polong. Jurnal Buletin Plasma Nutfah, 15(1), 27-31.

Bachtiar T. \& Waluyo, S.H. (2013). Pengaruh pupuk hayati terhadap pertumbuhan dan serapan nitrogen tanaman kedelai (Glycine max. L.) Varietas Mitani dan Anjasmoro. Widyariset. 16 (3), 411418.DOI::10.14203/widyariset.16.3.2013. 411418.

Baliadi Y., Tengkano, W. \& Marwoto. (2008). Penggerek polong kedelai Etiella zinckenella. Treitschke (Lepidoptera: Pyralidae), dan strategi pengendaliaannya di Indonesia. Jurnal Litbang Pertanian, 27, 113123.

Balai Penelitian Tanaman Aneka Kacang \& Umbi. (2016). Deskripsi Varietas Unggul Aneka Kacang dan Umbi. Badan Penelitian dan Pengembangan Pertanian, Balai Penelitian Tanaman Aneka Kacang dan Umbi, Malang.
Bayu, M. S. Y. I., Tantawizal \& Prayogo, Y. (2015). Tingkat serangan penggerek polong pada genotife kedelai toleran ulat grayak. Pros. Sem. Nas. Hasil Penelitian Tanaman Aneka Kacang dan Umbi Peran Inovasi Teknologi Aneka Kacang dan Umbi dalam Mendukung Program Kedaulatan Pangan.

Bayu, M.S.Y.I., Krisnawati, A. \& Adie, M.M. (2017). Respon genotipe kedelai biji besar dan umur genjah terhadap kompleks hama pengisap polong. J. HPT Tropika,17(2),128-136. DOI: http://dx.doi.org/ 10.23960/j.hptt.217128-136.

Djuwarso, T., Suryawan \& Rahardjo. (1990). Pengaruh populasi larva penggerek polong Etiella spp. dan stadia tanaman terhadap kerusakan polong dan biji serta hasil panen.Seminar Hasil Penelitian Tanaman Pangan Balai Penelitian Tanaman Pangan Bogor, 21-22 Februari 1990.

Dwiputra, A.H., Indradewa, D. \& Susila, E.T. (2015). Hubungan komponen hasil dan hasil tiga belas kultivar kedelai (Glycine max (L.) Merr.). Vegetalika, 4(3), 14-28.

Efendi. (2010). Peningkatan pertumbuhan dan produksi kedelai melalui kombinasi pupuk organik lamtoro gung dengan pupuk kandang. J.Floratek,5(4),65-73.

Fachrudin, L. (2000). Budidaya Kacang-Kacangan. Kanisius, Yogyakarta.

Kementerian Pertanian Republik Indonesia. 2018. Produksi Kedelai Menurut Provinsi. https:// www.pertanian.go.id/home/?show=page \&act $=$ view\&id=61. 6 Oktober 2019 .

Kriswantoro H., Murniati, N., Ghulamahdi. M. \& Agustina, K. (2012). Uji Adaptasi Varietas Kedelai di Lahan Kering Kabupaten Musi Rawas Sumatera Selatan. Prosiding Simposium dan Seminar Bersama PERAGI-PERHORTI-PERIPI-HIGI. 1-2 Mei 2012.

Marwoto \& Suharsono. (2010). Strategi dan komponen teknologi pengendalian ulat grayak (Spodoptera ltura Fabricius) pada tanaman kedelai. Jurnal Litbang Pertanian, 27(4), 131-136.

Marwoto, S. Hardaningsih, \& Taufiq, A. (2017). Hama dan Penyakit Tanaman Kedelai : Identifikasi dan Pengendaliannya. Pusat Penelitian dan Pengembangan Tanaman Pangan.

Minarno E.B., \& Khoiriyah, I. (2011). Ketahanan galur kedelai (Glycine max L) terhadap serangan ulat grayak (Spodoptera litura F.) berdasarkan karateristik trikoma. El-Hayah Jurnal Biologi, 2(1), 7-14. DOI: http://dx.doi.org/10.18860/ elha.v2i1.1792.

Ridhayat, I. R. (2012). Perkembangan populasi hama dan musuh alami kedelai Edamame (Glycine $\max$ Varietas Edamame) pada fase fegetatif dan Generatif. Institut Pertanian Bogor, Bogor.

Sari, K.P. \& Suharsono. (2010). Trikoma sebagai faktor ketahanan kedelai terhadap hama penggerek polong. Buletin Palawija, 20(1), 80-83. 
Soegito \& Arifin, (2004). Pemurnian dan Perbanyakan Benih Penjenis Kedelai. Badan Penelitian Tanaman Pangan, Malang.

Suharsono \& Suntono. (2004). Preferensi peneluran hama penggerek polong pada beberapa galur varietas kedelai. Jurnal Penelitian Pertanian Tanaman Pangan, 23 (1), 38-43.

Suharsono. (1997). Identifikasi Senyawa Khemis dan Karakter Morfologis yang Berperan dalam Ketahanan Tanaman Kedelai Terhadap Hama Pengisap Polong. Laporan Hasil Penelitian Tahun 1996/1997. Balai Penelitian Tanaman Aneka Kacang dan Umbi, Litbang Pertanian, Malang..

Suharsono. (2001). Kajian aspek ketahanan beberapa genotipe kedelai terhadap hama pengisap polong Riptortus linearis F. (Hem:Alydidae). Disertasi Doktor. Universitas Gadjah Mada, Jogjakarta.

Sumardi. (2014). Pertumbuhan dan Hasil Beberapa Varietas Kedelai (Glycine max L.) Terhadap Jenis Pupuk Pelengkap Cair. Skripsi. Program StudiAgroteknologi.Fakultas Pertanian Universitas Tamansiswa, Padang.

Susanto, G.W.A. \& Adie, M.M. (2008). Penciri ketahanan morfologi genotipe kedelai terhadap hamapenggerekpolong. J. Penelitian Pertanian Tanaman Pangan, 27(2), 1-6.
Tamang, S., Venkatarao, P. \& Chakrabotty, G. (2017). Varietal screening of mungbean cultivars for resistance/tolerance against insect pests under the Terai Agro-ecological zone of West Bengal. International Journal of Plant Protection, 10(1), 713. DOI: https://10.15740/has/ijpp/ 10.1/7-13.

Tengkano, W., Supriyatin, Suharsono, Bedjo, Prayogo, Y. \& Purwantoro. 2007. Status hama kedelai dan musuh alami di lahan kering masan Lampung. Iptek Tanaman Pangan, 2(1), 93-109.

Tohamy, HT., El-Hafez, G.A. (2005). Integrated crop management system for controlling cowpea pod worm, Etiella zinckenella (Treit.) in relation to soybean yield at Minia and new valley regions. Egyptian J AgricRes, 83, 1079-1098.

Utama, M.Z.H. (2008). Mekanisme fisiologi toleransi cekaman aluminium pada spesies legum penutup tanah terhadap metabolisme Nitrat (NO3-), Amonium $\left(\mathrm{NH}_{4}^{+}\right)$, dan Nitrit $\left(\mathrm{NO}_{2}{ }^{-}\right)$. Buletin Agron, 36 (2), 175-179. DOI: https://doi. org / 10.24831/jai.v36i2.20515. 